\title{
MODEL KOMUNIKASI GURU DALAM MENINGKATKAN MOTIVASI BELAJAR
} Studi pada Siswa Sekolah Dasar Negeri 27 Jelitik Sungailiat Bangka

\author{
Eqi Fitri Marehan \\ marehaneqi@gmail.com \\ Program Studi Ilmu Komunikasi Sekolah Tinggi IImu Sosial dan IImu Politik Pahlawan 12 Bangka
}

\begin{abstract}
ABSTRAK
Penelitian ini membahas komunikasi interpersonal guru dalam model interaksional untuk meningkatkan motivasi belajar siswa Sekolah Dasar Negeri 27 Jelitik Sungailiat Bangka. Teori yang digunakan adalah model interaksional. Jenis penelitian yang digunakan adalah deskriptif dengan pendekatan kualitatif. Teknik pengumpulan data menggunakan wawancara, observasi, dan dokumentasi. Hasil penelitian komponen input bertujuan memotivasi guru pelajaran, guru kelas, dan siswa-siswa untuk mengikuti proses belajar mengajar dengan baik agar nilai siswa menjadi baik sehingga memudahkan langkah-langkah para guru dalam memajukan kualitas proses belajar mengajar. Komponen proses, yakni komunikator, adalah para guru termasuk kepala sekolah. Gaya komunikasi dilakukan dua arah, komunikasi verbal dan nonverbal. Komponen output berupa sikap berubah siswa lebih baik, lebih percaya diri. Efeknya adalah guru termotivasi memajukan kualitas pembelajaran sehingga bisa menjadi lebih baik dan menjadikan SD Negeri 27 Jelitik ini sebagai role model bagi sekolah lainnya yang ada di gugus yang sama.
\end{abstract}

Kata Kunci: Komunikasi Interpersonal, Model Interaksional

\section{PENDAHULUAN}

Pembangunan pendidikan selalu terkait dengan peningkatan mutu hasil belajar. Menurut Nurhidayah, rendahnya hasil belajar di sekolah dikarenakan siswa tidak memiliki motivasi belajar yang tentunya datang dari komunikasi interpersonal guru. Kondisi ini disebabkan juga karena komunikasi antara guru dan siswa masih kurang optimal. Hal ini dapat dilihat dari kurangnya empati guru terhadap keadaan siswa, contohnya adalah guru kurang perhatian ketika ada siswa yang berhari-hari tidak masuk sekolah. Selain itu, guru kurang bersedia terbuka dalam menerima masukan siswa. Guru juga hanya sebagai pemberi materi belajar; ketika selesai memberikan materi, guru langsung memberikan tugas tertulis tanpa memberikan kesempatan kepada siswa untuk bertanya. Singkatnya, kurang interaksi yang terbuka antara guru dan siswa (Nurhidayah, 2013: 41).

Kendala seperti kurangnya komunikasi interpersonal guru dengan siswa ini membutuhkan penyelesaian yang serius karena siswa sebagai penerus bangsa harus diperhatikan oleh semua kalangan, khususnya oleh semua pihak yang terkait di sekolah seperti-salah satunya-guru. Bagaimanapun juga guru adalah sosok yang paling berperan penting untuk membuat siswa bisa mencapai tujuan pembelajaran, yaitu menambah pengetahuan dan meningkatkan prestasi belajar siswa.

Penulis mengamati proses belajar mengajar di SD Negeri 27 Sungailiat. Hasil temuan di lapangan adalah sebagian guru honorer kurang antusias dalam memberikan kesempatan kepada siswa untuk bertanya. Ditemukan pula cara guru dalam mendidik siswa yang kurang disiplin dengan memberikan hukuman berupa berdiri di bawah tiang bendera sampai jam istirahat tiba. Demikian pula hukuman bagi siswa yang tidak mengerjakan PR, siswa disuruh berdiri di depan kelas seraya mengangkat salah satu kakinya. Bahkan, yang sangat disayangkan, masih ditemukan oknum guru yang memberikan hukuman fisik dengan cara memukuli siswa menggunakan mistar kayu.

Kasus-kasus kekerasan seperti di atas menyebabkan siswa tidak termotivasi dalam belajar, dan pada saat yang sama hak-hak siswa hanya sebatas mendengar. Guru seolah-olah tidak mau tahu apa yang menjadi faktor utama penunjang guru dalam proses belajar mengajar, yaitu komunikasi interpersonal. Idealnya, komunikasi interpersonal guru terhadap siswa harus selalu dibina karena begitu erat kaitan komunikasi interpersonal guru dengan motivasi belajar siswa. Apabila guru 
melakukan komunikasi secara tatap muka dan dari hati ke hati dengan siswanya, maka siswa akan merasa senang dan bersemangat dalam belajar.

Berdasarkan latar belakang masalah di atas, penulis membuat penelitian yang berjudul "Komunikasi Interpersonal Guru dalam Model Interaksional untuk Meningkatkan Motivasi Belajar Siswa Sekolah Dasar Negeri 27 Jelitik Sungailiat Bangka.”

\section{TINJAUAN PUSTAKA}

\section{Komunikasi}

Komunikasi merupakan sebuah kata yang abstrak dan memiliki sejumlah arti. Kata "komunikasi" berasal dari bahasa latin, yaitu communis, yang berarti "sama" atau communicare yang berarti "membuat sama" (Mulyana, 2001: 41). Singkatnya, istilah komunikasi sudah sedemikian lazim di kalangan kita semua, meskipun masing-masing orang mengartikannya secara berlainan (Effendy, 2001: 15).

Fungsi komunikasi, menurut Effendy (2003: 55), antara lain: 1) menyampaikan informasi, yakni memberikan informasi kepada masyarakat tentang hal-hal yang terjadi; menyampaikan gagasan dan tingkah laku orang lain, serta segala sesuatu yang disampaikan orang lain; 2) mendidik (to educated); komunikasi merupakan alat untuk mendidik, dalam hal ini bagaimana kita menyampaikan ide dan gagasan kita kepada orang lain dalam rangka mendidik orang tersebut dengan ilmu pengetahuan yang didapatkan; 3) menghibur (to entertain); komunikasi berguna menghibur orang lain atau memberikan kesenangan pada orang lain; 4) mempengaruhi (to influence); fungsi mempengaruhi yang dimaksud adalah bagaimana komunikasi bisa mempengaruhi tingkah laku seseorang sesuai dengan informasi yang didapatkan dan diharapkan.

\section{Definisi Komunikasi Interpersonal}

Wiryanto (2004: 32) menjelaskan bahwa komunikasi interpersonal merupakan komunikasi yang berlangsung dalam situasi tatap muka dua orang atau lebih, baik secara terorganisasi maupun pada kerumunan orang.

Menurut Effendy (2003: 60), komunikasi interpersonal adalah proses pengiriman dan penerimaan pesan-pesan antara dua orang atau di antara kelompok kecil orang-orang dengan beberapa elemen dan beberapa umpan balik seketika.

\section{Efektivitas Komunikasi Interpersonal}

Menurut Kumar dalam Wiryanto (2004: 36), efektivitas komunikasi interpersonal memiliki lima ciri, yakni: 1) keterbukaan (openness) adalah kemauan menanggapi dengan senang hati informasi yang diterima di dalam menghadapi hubungan antarpribadi; 2) empati (empathy) adalah merasakan apa yang dirasakan orang lain; 3) dukungan (supportiveness) adalah situasi yang terbuka untuk mendukung komunikasi berlangsung efektif; 4) rasa positif (positiveness), seseorang harus memiliki perasaan positif terhadap dirinya, mendorong orang lain lebih aktif berpartisipasi, dan menciptakan situasi komunikasi kondusif untuk interaksi yang efektif; 5) kesetaraan (equality) adalah pengakuan secara diam-diam bahwa kedua belah pihak menghargai, berguna dan mempunyai sesuatu yang penting untuk disumbangkan.

\section{Teori-teori Hubungan Interpersonal}

Suranto (2011: 36) menyebutkan ada empat teori atau model hubungan interpersonal, yaitu model pertukaran sosial, model peranan, model permainan, dan model interaksional. Dalam penelitian ini penulis menjelaskan mengenai model interaksional sebagai grand theory untuk menjelaskan keterhubungan komunikasi interpersonal dengan motivasi belajar siswa.

Model interaksional memandang hubungan interpersonal sebagai sebuah sistem. Setiap sistem terdiri dari subsistem-subsistem atau komponen-komponen yang saling tergantung dan bertindak bersama sebagai suatu kesatuan untuk mencapai tujuan tertentu. Johnson, Kast, dan Rosenzweig menjelaskan ada tiga komponen sistem, yaitu input, proses (pengolah), dan output. Input merupakan komponen penggerak; proses (pengolah) merupakan sistem operasi; output menggambarkan hasil-hasil kerja sistem (Suranto, 2011: 40). 
Gambar 1: Hubungan Interpersonal sebagai Sistem

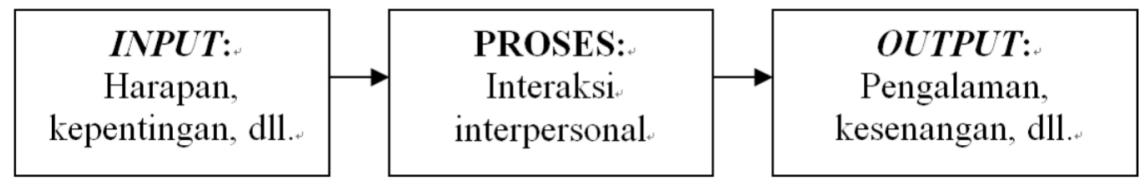

(Sumber: Suranto, 2011: 40)

Gambar di atas menunjukkan bahwa terjadinya hubungan interpersonal disebabkan adanya input, yaitu suatu hasrat tertentu yang menggerakkan perilaku. Misalnya: untuk menepis situasi yang sepi, kita mengontak teman. Dalam contoh ini ada input berupa keinginan mengusir perasaan sepi, yang menggerakkan kita menghubungi teman. Lalu terjadilah proses berupa perbincangan antara kita dan seorang teman. Dari proses perbincangan ini menghasilkan output, misalnya memperoleh suasana kehangatan.

\section{Motivasi Belajar}

Motivasi belajar yang tinggi tercermin dalam ketekunan yang tidak mudah patah semangat, atau pantang menyerah, sebelum mendapatkan apa yang diinginkan. Motivasi yang tinggi dapat mengarahkan dan menggiatkan siswa untuk mengikuti proses belajar mengajar (Muhammad, dkk., 2013: 57).

\section{METODE PENELITIAN}

Jenis Penelitian ini adalah kualitatif dengan menggunakan metode deskriptif. Penelitian kualitatif adalah prosedur penelitian yang menghasilkan data-data deskriptif berupa kata-kata tertulis dan lisan dari orang-orang dan pelaku yang diamati. Penelitian kualitatif yang dilakukan bersifat deskriptif, yaitu penelitian yang memberikan gambaran mengenai situasi yang diteliti dalam bentuk naratif (Zuriah, 2005: 92).

Menurut Nawawi (2003: 63), metode deskriptif dapat diartikan sebagai prosedur pemecahan masalah yang diselidiki dengan menggambarkan atau melukiskan keadaan subjek atau objek penelitian (seseorang, lembaga, masyarakat, dan lain-lain) pada saat ini berdasarkan fakta-fakta yang tampak.

\section{Teknik Pengumpulan Data}

Pengumpulan data merupakan suatu langkah dalam metode ilmiah yang melalui prosedur sistematis, logis, dan proses pencarian data yang valid, baik diperoleh secara langsung (primer) ataupun tidak langsung (sekunder), untuk keperluan analisis dan pelaksanaan pembahasan suatu penelitian secara benar untuk menemukan kesimpulan, memperoleh jawaban, dan sebagai upaya untuk memecahkan suatu persoalan yang dihadapi oleh peneliti (Ruslan, 2010: 26).

Teknik pengumpulan data merupakan langkah yang paling strategis dalam penelitian karena tujuan utama dari penelitian adalah mendapatkan data. Tanpa mengetahui teknik pengumpulan data, peneliti tidak akan mendapatkan data yang memenuhi standar data yang ditetapkan (Sugiyono, 2009: 62).

Dalam penelitian ini penulis menggunakan beberapa teknik pengumpulan data, yakni sebagai berikut:

\section{Wawancara}

Menurut Moleong (2008: 186), wawancara adalah percakapan yang dilakukan oleh dua pihak, yaitu pewawancara yang mengajukan pertanyaan dan terwawancara yang memberikan jawaban atas pertanyaan itu. Dalam penelitian ini, yang menjadi narasumber utama atau informan kunci adalah kepala SD Negeri 27 yang bernama Rafini S.Pd., sedangkan narasumber pendukung lainnya adalah guru-guru SD Negeri 27, yakni Mega Mustika, S.Pd. dan Eka Rahayuningsih, S.Pd. Narasumber lainnya adalah 3 orang siswa SD Negeri 27 Jelitik: Ikhwan (kelas IV), Danang (kelas V), dan Sintia Purnama (kelas V).

2. Observasi

Menurut Riduwan (2004: 104), observasi merupakan teknik pengumpulan data, dengan peneliti melakukan pengamatan secara langsung ke objek penelitian untuk melihat dari dekat kegiatan yang dilakukan. Dalam penelitian ini, peneliti melakukan observasi pada narasumber (yakni guru kelas) mengajar. Dalam situasi mengajar tersebut, interaksi antara guru dan siswa dalam bentuk komunikasi interpersonal akan diamati oleh peneliti yang nantinya menjadi catatan di lapangan untuk data yang menguatkan hasil wawancara narasumber. 


\section{Dokumentasi}

Data-data hasil dokumentasi dalam penelitian ini antara lain berupa buku-buku, literatur, internet, dan dokumen berupa data-data tentang SD N 27 Sungailiat.

\section{Teknik Analisis Data}

Analisis data adalah proses mencari dan menyusun data secara sistematis yang diperoleh dan hasil wawancara dan temuan agar dapat diinformasikan kepada orang lain (Bogdan dalam Sugiyono, 2009: 244). Terdapat tiga komponen pokok aktivitas dalam analisis kualitatif yang dapat dilihat pada gambar berikut (Miles dan Huberman, dalam Sugiyono, 2009: 246).

\section{Gambar 2: Komponen Analisis Data Model Interaktif}

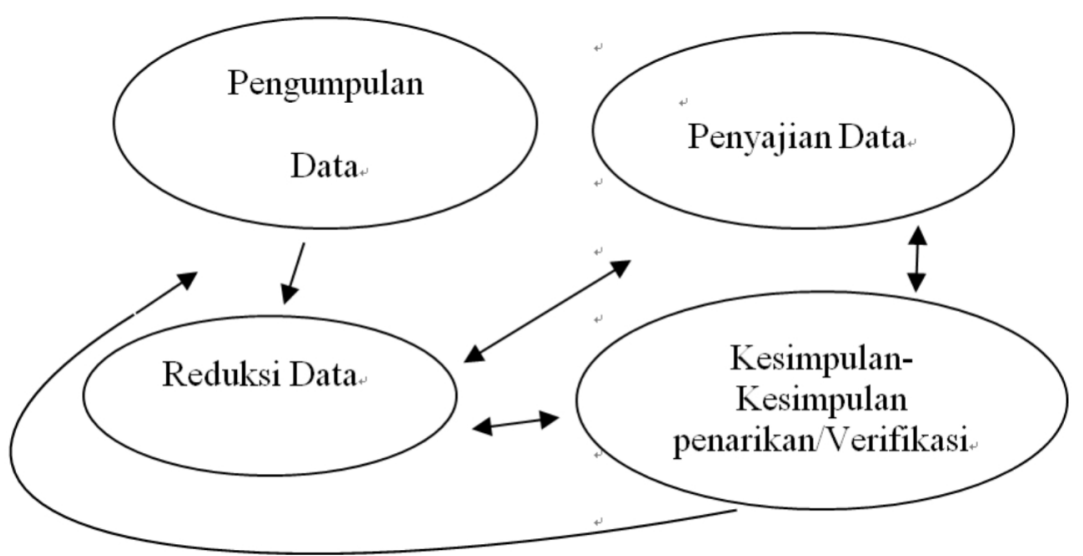

(Sumber: Miles dan Huberman dalam Sugiyono, 2009: 246).

Data reduction (reduksi data) diartikan sebagai proses pemilihan, pemusatan perhatian pada penyederhanaan, pengabstrakan dan transformasi data kasar yang muncul dan catatan-catatan hasil penelitian di lapangan. Melalui kegiatan ini, peneliti dapat menggolongkan, mengarahkan dan mengorganisasikan data sehingga dapat menarik kesimpulan akhir. Data display (penyajian data) merupakan rangkaian informasi yang didapat dari hasil wawancara, observasi, studi pustaka maupun sumber lain. Conclusion drawing/vrification (menarik kesimpulan atau verifikasi) merupakan langkah terakhir dan kegiatan analisis kualitatif. Penerapan kesimpulan ini bergantung pada besarnya kumpulan catatan di lapangan.

\section{Validasi Data}

Validitas data dalam penelitian ini menggunakan analisis triangulasi, yaitu menganalisis jawaban subjek dengan melakukan memeriksa kebenarannya dengan data empiris atau sumber data lainnya yang tersedia. Dalam hal ini jawaban subjek dilakukan cross-check dengan dokumen yang ada. Menurut Sugiyono (2007: 127), triangulasi sumber dilakukan untuk menguji kredibilitas data dengan cara mengecek data yang telah diperoleh melalui beberapa sumber. Data dari beberapa sumber tersebut tidak bisa dicarikan angka rata-rata sebagaimana pada penelitian kuantitatif, namun dideskripsikan dan dikategorikan berdasarkan pandangan yang sama, yang berbeda, maupun yang spesifik dari tiga sumber tersebut. Data yang telah dianalisis oleh peneliti menghasilkan suatu kesimpulan yang selanjutnya dimintakan kesepakatan (member check) dengan tiga sumber data tersebut.

\section{HASIL DAN PEMBAHASAN}

Pembahasan hasil penelitian berisi penyajian hasil wawancara peneliti sebagai salah satu teknik pengumpulan data primer setelah proses observasi. Hasil wawancara dengan narasumber, yakni kepala SD Negeri 27 Sungailiat (Ibu Rafini), guru Pendidikan Agama Islam (Ibu Rokiah), guru Kelas III (Ibu Lita Septiani), guru Kelas IV (Ibu Kasma R. Cik), guru Kelas V (Ibu Mega Mustika), dan guru Kelas VI (Ibu Fitri Yessi Herawati).

Hasil wawancara kemudian dikombinasikan dengan dokumentasi yang peneliti peroleh dari tempat penelitian, yakni SD Negeri 27 Jelitik Sungailiat, untuk mengetahui komunikasi interpersonal guru dalam 
model interaksional dalam meningkatkan motivasi belajar SD Negeri Jelitik Sungailiat Bangka. Selain itu, hasil wawancara dikaji dengan sumber-sumber pustaka yang terkait tentang model interaksional.

\section{Hasil Analisis Komponen Input}

Berdasarkan hasil wawancara dengan narasumber dan dilengkapi hasil observasi peneliti, dapat diketahui input dalam model komunikasi. Dalam konteks ini model interaksional itu adalah komunikasi interpersonal dan siswa SD Negeri 27 Jelitik Sungailiat Bangka. Hasil penelitian ini memberikan dukungan dan motivasi kepada guru pelajaran, guru kelas, dan siswa-siswa untuk mengikuti proses belajar mengajar dengan baik agar nilai siswa menjadi baik, di samping memberikan bantuan (konseling), mengungkapkan perhatian pada peserta didik, serta membangun dan memelihara hubungan yang harmonis. Penelitian juga berupaya untuk mengetahui karakteristik diri pribadi dan orang lain, khususnya siswa. Dengan demikian, guru dapat berkomunikasi dengan siswa secara menarik dan nyaman dalam proses belajar mengajar.

Adapun harapan setelah melakukan komunikasi interpersonal pada saat proses belajar mengajar di SD Negeri 27 Jelitik Sungailiat adalah terbinanya hubungan baik antar-guru dan guru dengan siswa; termotivasinya siswa dalam proses pembelajaran sehingga meningkatkan nilai prestasi; meningkatnya keaktifan dan pengetahuan siswa; berubahnya sikap siswa menjadi lebih baik. Kepentingan dan motivasi yang menjadi alasan melakukan komunikasi interpersonal saat proses belajar mengajar adalah meningkatkan kualitas pembelajaran peserta didik di SD Negeri 27 Jelitik Sungailiat sehingga bisa menjadi role model bagi sekolah yang lain, di samping mengontrol perkembangan siswa dengan menciptakan kedekatan dengan para siswa sehingga guru dapat mengetahui dan memahami masalah masing-masing siswa dan mencari pemecahan permasalahan tersebut. Adapun hal yang dirasakan senang oleh guru terkait komunikasi interpersonal pada saat proses belajar mengajar adalah saat siswa antusias berkomunikasi. Artinya, komunikasi yang dilakukan guru ada feedback, ataupun komunikasi berlangsung dua arah. Jadi, tidak hanya guru yang menyampaikan informasi tapi juga ada respons dari siswa.

Hal melandasi guru melakukan komunikasi interpersonal pada saat proses belajar mengajar adalah sejauh mana hubungan antara para pendidik dan siswa terjalin, sejauh mana kemauan dan kemampuan para guru dalam mendidik, dan sejauh mana kemampuan siswa dalam menerima pembelajaran. Dari sini guru dapat memetakan langkah-langkah ke depan dalam rangka memajukan kualitas proses belajar mengajar, serta mengetahui dan mengenali karakteristik diri pribadi, berdasarkan informasi dari peserta didik.

\section{Hasil Analisis Komponen Proses}

Berdasarkan pemaparan hasil wawancara peneliti dengan narasumber serta hasil observasi peneliti, dapat diketahui proses dalam model komunikasi interaksional guru untuk meningkatkan motivasi belajar siswa SD Negeri Negeri 27 Jelitik Sungailiat Bangka. Komunikator atau orang yang menyampaikan informasi atau pesan dalam komunikasi interpersonal pada saat proses belajar mengajar adalah para guru termasuk kepala sekolah. Gaya komunikasi yang digunakan saat proses belajar mengajar adalah komunikasi dua arah mengedepankan diskusi sebagai salah satu metode pembelajaran agar dapat melatih kemampuan analisis atau nalar siswa. Komunikasi menggunakan bahasa verbal dan nonverbal; komunikasi ini berbaur dengan pembicaraan langsung misalnya dari gerakan, ekspresi wajah, dan karakteristik suara. Adapun nilai yang ditekankan pada gaya komunikasi adalah kesopanan dan penggunaan bahasa yang baik saat proses komunikasi interpersonal berlangsung.

Kejelasan guru dalam menyampaikan pesan berupa materi pelajaran cukup jelas dari pengucapan kata-kata atau artikulasi. Volume suara saat menyampaikan materi adalah suara yang lantang dan tegas karena jumlah siswa dalam satu kelas yang tidak sedikit. Hal ini berbeda pada saat berkomunikasi face to face dengan siswa yang diajak berbicara langsung untuk mengetahui permasalahan yang dihadapinya, yakni lebih bersifat pribadi. Jadi, volume suara guru disesuaikan dengan kondisi tempat berkomunikasi dan kondisi siswa.

Saat berkomunikasi interpersonal seperti pada waktu guru menyampaikan materi, ada guru yang terkadang menyampaikan materi dengan cepat dan ada yang dengan perlahan. Hal ini tentunya juga turut mempengaruhi daya tangkap dari komunikan yakni para siswa. Gesture komunikator juga mempengaruhi proses dalam meningkatkan motivasi komunikan, yakni siswa lebih giat belajar. Gesture tubuh guru menunjukkan keseriusan; saat menulis di papan tulis mereka berdiri dengan tegak, ekspresi wajah serius sehingga siswa bisa fokus memperhatikan. Saat duduk di kursi guru juga dalam keadaan tegak menghindari tidur di kelas atau 
bermain handphone. Bagaimanapun juga siswa bisa menilai gaya guru yang terkadang ketika di rumah mereka sampaikan kepada orang tua masing-masing.

Ada tiga isi pesan verbal yang disampaikan komunikator (guru). Pertama, materi pembelajaran. Kedua, motivasi atau membangun percaya diri peserta didik-terutama-saat siswa akan menghadapi ujian. Saat hendak menghadapi ujian, pesan-pesan motivasi terus dikemukakan guru; guru mengingatkan siswa supaya giat dan tekun belajar di rumah untuk mendapatkan nilai yang bagus. Ketiga, memberikan pujian sebagai penguatan kepada peserta didik. Misalnya ketika siswa mendapatkan nilai yang baik, guru memberikan pujian seperti: "Bagus, nilainya semakin bagus, belajar terus agar mendapat nilai yang bagus lagi ya, Nak.”

Pesan nonverbal bisa melalui beberapa media. Pertama, ekspresi wajah dan kontak mata guru saat menyampaikan materi dengan mimik wajah serius supaya siswa juga serius. Kedua, menggunakan alat bantu untuk menyampaikan informasi pada siswa, misalnya gambar yang ditunjukkan dari buku. Ketiga, gerakan tubuh guru yang mengungkapkan antusiasme dan semangat untuk terus belajar, misalnya melalui kepalan tangan menunjukkan semangat dan meminta siswa mengikuti gerakan-gerakan yang bisa memotivasi.

Komunikan yang menerima informasi atau pesan dalam komunikasi interpersonal dalam komunikasi interpersonal pada saat proses belajar mengajar adalah para peserta didik atau siswa SD Negeri 27 Jelitik Sungailiat Bangka. Berdasarkan observasi penulis di lapangan, gesture komunikan saat menerima pesan dalam komunikasi interpersonal pada saat proses belajar mengajar ada yang serius hingga duduk tegak, ada yang mengantuk dan bahkan tertidur di kelas, ada yang sibuk bermain-main dengan teman, ada juga yang mengobrol. Gesture komunikan dalam menerima pesan disebut dengan decoding. Contohnya siswa mendengar gurunya menyampaikan informasi mengenai pelajaran, maka melalui apa yang ia dengar dan ia lihat di kelas timbul sebuah persepsi atau pemahaman terhadap pelajaran tersebut.

Karakteristik siswa yang beragam tentunya mempengaruhi daya tangkap mereka dalam menerima pelajaran. Hal ini merupakan hambatan selama proses komunikasi interpersonal pada saat proses belajar mengajar. Namun, sebagian besar guru terkesan menyamaratakan siswa walaupun tingkat kecerdasan dan pemahaman siswa berbedabeda. Di sinilah guru dituntut untuk lebih memahami siswanya dan memiliki kreativitas yang baik. Strategi yang dilakukan untuk mengatasi hambatan tersebut adalah: 1) guru harus lebih banyak sabar, tidak cepat marah dengan apa yang dilakukan siswa; 2) kemampuan menarik perhatian siswa agar terkonsentrasi pada apa yang disampaikan guru. Menarik perhatian siswa sangat diperlukan, misalnya dengan memukul-mukul meja supaya menimbulkan bunyi sehingga mengalihkan siswa yang sibuk mengobrol sendiri dan kembali memperhatikan guru. Bentuk lain guru menarik perhatian adalah menyebutkan nama satu per satu siswa yang ribut supaya mereka kembali tertib. Dalam hal ini, sangatlah penting kemampuan guru dalam mengenali karakteristik siswa dan mengetahui penanganan yang baik untuk menghadapi siswa. Dalam kondisi yang sukar ditangani, sebagian guru memilih memanggil orang tua siswa untuk ke sekolah agar mengingatkan kekurangan-kekurangan yang dimiliki anaknya dan bagaimana andil atau kerja sama orang tua untuk mengatasi persoalan tersebut.

\section{Hasil Analisis Komponen Output}

Berdasarkan hasil wawancara dengan narasumber, dapat diketahui output dalam model interaksional dalam komunikasi interpersonal guru SD Negeri 27 Jelitik Sungailiat Bangka. Ada perubahan sikap siswa sebagai komunikan setelah komunikasi interpersonal dalam komunikasi interpersonal pada saat proses belajar mengajar. Keadaan siswa lebih baik dibandingkan saat sebelum dilangsungkan komunikasi interpersonal. Sebagai contoh adalah cara berpikir siswa lebih matang, lebih giat belajar, lebih bersungguh-sungguh. Begitu pula dalam sikap, siswa berubah lebih baik dan lebih percaya diri. Sebagai catatan, tidak semua siswa dalam satu kelas mengalami perubahan tersebut.

Adapun pengalaman para guru yang melakukan komunikasi interpersonal dengan peserta didik adalah mendapatkan pengetahuan mengenai beragam karakteristik peserta didik dan cara-cara menangani masing-masing siswa. Dari sini guru dapat lebih mudah untuk mendekati dan memotivasi siswa dalam hal pembelajaran. Selain itu, guru perlu melakukan introspeksi diri: apa kelemahan dalam berkomunikasi agar setiap siswa bisa berubah lebih baik.

Mengenai nilai pelajaran yang didapat siswa setelah komunikasi interpersonal berlangsung dengan para guru, hasilnya adalah cukup baik. Dalam hal ini ada peningkatan walaupun tidak bisa dikatakan peningkatan yang signifikan. Pasalnya 
adalah karakteristik siswa yang berbeda-beda; mulai dari daya tangkap, daya ingat, dan kemampuan pemahaman siswa.

\section{Hasil Analisis Efek}

Berdasarkan hasil wawancara peneliti dengan narasumber, dapat diketahui efek dalam model interaksional dalam konteks komunikasi interpersonal guru Sekolah Dasar Negeri 27 Jelitik Sungailiat Bangka. Dalam hal ini guru termotivasi untuk memajukan kualitas pembelajaran agar bisa menjadi lebih baik dan menjadikan SD Negeri 27 Jelitik sebagai role model bagi sekolah lainnya yang ada di gugus yang sama. Guru termotivasi untuk lebih menghargai dan memelihara hubungan baik dengan siswa guna meningkatkan kualitas pembelajaran selanjutnya.

Adapun bentuk motivasi yang dirasakan para guru adalah keinginan melakukan yang lebih baik untuk guru-guru dan peserta didik, serta motivasi untuk mendalami karakter masing-masing siswa.

\section{KESIMPULAN DAN SARAN}

Berdasarkan hasil pembahasan dapat disimpulkan bahwa komponen input bertujuan memberikan dukungan dan motivasi kepada guru pelajaran, guru kelas, dan siswa-siswa untuk mengikuti proses belajar mengajar dengan baik agar nilai siswa menjadi baik sehingga memudahkan langkah-langkah guru memajukan kualitas proses belajar mengajar.

Komponen proses, yakni komunikator, adalah para guru, termasuk kepala sekolah. Gaya komunikasi yang berlangsung adalah komunikasi dua arah dengan mengedepankan diskusi sebagai salah satu metode pembelajaran agar dapat melatih kemampuan analisis atau penalaran siswa.

Komponen output yang dicapai adalah perubahan sikap siswa, dalam hal ini cara berpikir siswa lebih matang, lebih giat belajar, lebih bersungguh-sungguh, sikap berubah lebih baik (semisal lebih percaya diri). Sayangnya, tidak semua siswa dalam satu kelas mengalami perubahan tersebut.

Efek yang diketahui adalah guru termotivasi terutama untuk memajukan kualitas pembelajaran sehingga bisa menjadi lebih baik dan menjadikan SD Negeri 27 Jelitik sebagai role model bagi sekolah lainnya yang ada di gugus yang sama.

Selain itu, berdasarkan kesimpulan dalam penelitian, peneliti memberikan beberapa rekomendasi kepada guru-guru dan kepala SD Negeri 27 Jelitik Sungailiat Bangka:

1. Pada komponen input, guru harus menetapkan tujuan, harapan, dan motivasi yang kuat untuk membangun komunikasi interpersonal pada semua peserta didik.

2. Pada komponen proses guru diharapkan meningkatkan kemampuan berkomunikasi atau berinteraksi dalam menghadapi bermacam-macam karakteristik siswa.

3. Pada komponen output diharapkan guru meningkatkan hasil dari nilai siswa yang menjadi output sebuah pembelajaran di sekolah. Hal ini merupakan salah satu barometer untuk mengetahui tingkat keberhasilan secara akademik tanpa mengesampingkan karakter peserta didik sebagai indikator sebuah keberhasilan pendidikan.

4. Pada aspek efek diharapkan guru tidak sekadar termotivasi untuk melakukan komunikasi interpersonal dan memperluas wawasan, namun juga menghadirkan inovasi dalam metode pembelajaran.

\section{DAFTAR PUSTAKA}

Aprilliani, Evi. (2017). "Peran Pesan Komunikasi Wali Kelas terhadap Motivasi Belajar Siswa Kelas X, XI Dan XII Jurusan Teknik Las SMK Negeri 2 Sungailiat”. Skripsi program studi Ilmu Komunikasi Sekolah Tinggi Ilmu Sosial dan Ilmu Politik Pahlawan 12 Sungailiat Bangka

Ardial. (2015). Paradigma dan Model Penelitian Komunikasi. Cetakan Kedua. Jakarta: Bumi Aksara

Arni, Muhammad. (2009). Komunikasi Organisasi. Jakarta: Bumi Aksara 
Azwar, Saifuddin. (2007). Metode Penelitian. Yogyakarta: Pustaka Pelajar

Dalyono. (2005). Psikologi Pendidikan. Jakarta: Rineka Cipta

Dermawan, Abdul Aziz. "Komunikasi Interpersonal Guru dan Siswa dalam Proses Pembelajaran Pendidikan Agama Islam di SMP Swasta Al-Hikmah Marelan”. Skripsi untuk program studi Pendidikan Agama Islam Fakultas Ilmu Tarbiyah dan Keguruan Universitas Islam Negeri Sumatera Utara. Diakses dari http://repository.uinsu.ac.id/5140/1/KOMUNIKASI\%20INTERPERSONAL\%20revisi\%20GURU\%20DAN\%20 SISWA\%20ahai.pdf

Djamarah, Syaiful Bahri. (2002). Psikologi Belajar. Rineka Cipta: Jakarta.

Effendy, Onong Uchjana. (2001). Ilmu Komunikasi: Teori dan Praktek. Bandung: Remaja Rosdakarya (2003). Ilmu Komunikasi: Teori dan Praktek. Bandung: Remaja Rosdakarya

Hadari, Nawawi. (2003). Metode Penelitian Bidang Sosial. Yogyakarta: Gadjah Mada University Press

Lexy, J Moleong. (2008). Metodologi Penelitian Kualitatif. Bandung: Remaja. Rosdakarya

Mulyana, Deddy. (2001). Prinsip-prinsip Dasar Komunikasi. Bandung: Remaja Rosdakarya

Nurhidayah, Septi. (2013). "Peningkatan Minat Belajar Siswa dalam Mata Pelajaran IPA Materi Indra dengan Menggunakan Media Audio Visual pada Siswa Kelas IV MI Klumpit Kecamatan Karanggede Kabupaten Boyolali Tahun Ajaran 2013/2014.” Skripsi untuk Jurusan Tarbiyah Pendidikan Guru Madrasah Ibtidaiyah Sekolah Tinggi Agama Islam Negeri (STAIN). Diakses dari http://erepository.perpus.iainsalatiga.ac.id/382/1/Septi\%20Nurhidayah_11509002.pdf

Purwanto. (2002). Evaluasi Hasil Belajar. Yogyakarta: Pustaka Pelajar

Rohim, Syaiful. (2009). Teori Komunikasi. Jakarta: Rineka Cipta

Ruslan, Rosady. (2010). Metode Penelitian: Public Relations dan Komunikasi. Jakarta: RajaGrafindo Persada

Sardiman, A.M. (2001). Interaksi dan Motivasi Belajar Mengajar. Jakarta: RajaGrafindo Persada

Slameto. (2003). Belajar dan Faktor-faktor yang Mempengarubinya. Jakarta: Rineka Cipta

Rumini, Sri, dkk. (2006). Psikologi Pendidikan. Yogyakarta: UNY Press

Sudjana, Nana. (2002). Penilaian Hasil Proses Belajar Mengajar. Bandung: Remaja Rosdakarya

Sugiyono. (2007). Metode Penelitian Kuantitatif, Kualitatif dan RED. Bandung: Alfabeta (2009). Metode Penelitian Kuantitatif Kualitatif dan RED. Bandung: Alfabeta

Sukandarrumidi. (2006). Metodologi Penelitian. Yogyakarta: Gadjah Mada University Press

Suranto, AW. (2011). Komunikasi Interpersonal. Yogyakarta: Graha Ilmu.

Suryabrata, Sumadi. 2002. Psikologi Pendidikan. Jakarta: Grafindo Perkasa Rajawali

Undang-undang Nomor 20 Tahun 2003 tentang Sistem Pendidikan Nasional

Widjaja, H.A.W. (2000). Ilmu Komunikasi Pengantar Studi. Bandung: Rineka Cipta

Wiryanto. (2004). Pengantar Ilmu Komunikasi. Jakarta: Gramedia Widiasarana

Zuriah, Nurul. (2005). Metodologi Penelitian Sosial dan Pendidikan. Jakarta: Bumi Aksara 